\title{
Comparison of quality characteristics between seasonal cultivar of salted-Kimchi cabbage (Brassica rapa L. ssp. Pekinesis)
}

\author{
Kyung Hyung $\mathrm{Ku}^{*}$, Eun Jeong Choi, Moon Cheol Jeong \\ Food Distribution System Research Group, Korea Food Research Institute, Seongnam 463-746, Korea
}

\section{계절별 절임배추의 품질 특성 비교}

\author{
구경형* · 최은정 · 정문철 \\ 한국식품연구원 유통시스템연구단
}

\begin{abstract}
This study was carried to investigate the physicochemical and microbiological characteristics of seasonal salted-Kimchi cabbage order to provide basic data for optimal salting and storage condition of seasonal Kimchi cabbage. Generally, fall season samples had slightly higher $\mathrm{pH}$ and acidity value than the other seasonal salted Kimchi cabbage. The soluble solids content of spring, summer, fall and winter samples were $5.95 \%, 6.18 \%, 6.29 \%$ and $7.76 \%$, respectively. The salt content of all the seasonal salted Kimchi cabbage samples were insignificant. The number of microbial bacteria in the summer samples were generally much more significant than spring and winter samples. There was no significant difference in the color of seasonal salted Kimchi cabbage. As for the texture properties, the firmest samples in the surface rupture test were the spring samples (force: $4.92 \mathrm{~kg}$ ), and the hardest samples in the puncture test were the summer samples (force: $11.71 \mathrm{~kg}$ ). In the correlation analysis of the quality characteristics of seasonal samples, the soluble solids content and hardness of the seasonal salted Kimchi cabbage was significantly correlated at $1 \%$ significance level. Also, in the principal component analysis, F1 and F2 were shown to explain $27.28 \%$ and $35.59 \%$ of the total variance $(62.87 \%)$, respectively. The hierarchical cluster analysis of the quality characteristics of seasonal samples, the samples were divided into three groups: spring cabbage group, summer cabbage group and fall and winter cabbage group,
\end{abstract}

Key words : seasonal cultivar, salted-Kimchi cabbage, quality characteristics

\section{서 론}

배추(Brassica campestris L. ssp. pekinensis)는 2000년 이 전에 지중해 연안에서 자라던 잡초성 유채 순무와 남부지방 의 숭(菘)이 중국 북부의 양주지방에서 자연 교잡되어 자란 것이 배추의 원시형이라고 전해지고 있다. 배추는 국내에 서 소비량이 가장 많은 채소로 재배시기에 따라 봄배추, 고랭지배추, 가을배추, 월동배추로 구분하고, 포기 형태로 는 결구형, 반결구형, 불결구형으로 분류한다(1,2). 배추 총 생산량은 2000년 314만 9천톤으로 가장 높았다가 재배면적 이 감소하여 2011년 301만 6천톤, 2012년 224만 3천 톤이었 다(3). 배추는 호냉성 채소로 생육초기에는 고온에서 발육 되다가 생육후기에는 서늘한 기후에서 결구가 촉진되는

*Corresponding author. E-mail : khku@kfri.re.kr

Phone : 82-31-780-9052, Fax : 82-31-709-9876
작물로 김장배추 위주로 재배되었다. 그러나 최근 육종 개 발에 의해 봄배추, 여름배추, 가을배추 및 월동배추 등이 육종되어 연중 출하가 가능해졌다(4). 우리나라 채소 생산 의 반 이상을 차치하고 있는 배추는 총 생산량의 약 $90 \%$ 이상이 배추 원물 상태로 유통되며 약 $82.5 \%$ 이상이 김치 제조에 사용하고 있다(5). 절임배추는 배추김치를 만들기 위한 주원료로 절임을 하는 과정은 배추김치를 만드는데 반드시 필요한 공정이다, 이러한 절임배추 제조 공정은 아 파트와 같은 주거지에서는 절임배추 제조가 어렵고, 시간 적으로 많이 소요되어 소비자들은 상품으로 판매되고 있는 고품질의 절임배추를 요구하게 되었다(6). 즉 가정에서 김 치를 제조하여 섭취하는 소비자의 경우 직접 절임배추를 제조하기보다 필요시에 절임배추를 구매하여 김치를 제조 하는 소비 패턴으로 변화되었다. 이에 따라 배추절임업체 와 김치 제조업체에서는 재배와 수확시기에 따라 봄 노지배 
추(5 7월 수확), 여름 고랭지배추(7 9월 수확), 가을 노지 배추(10 12월 수확), 월동배추(1 2월)로 나누어 절임배추 제조하여 연중 소비자에게 공급하고 있다.

한편 절임배추에 관한 연구는 절임배추를 저온 살균하여 스타터로서 김치 젖산균인 Leuconostoc. citreum Lactobacillus. plantarum을 첨가하여 김치 발효 중 발효 특성과 기능성 증진 효과, 전기 분해수를 이용한 절임 조건에 따른 배추의 품질 특성, 절임 방법에 따른 배추 조직 및 염도 변화 등이 있다(7-13). 또 현장형 연구로 대규모 김치 제조공장에서 작형별 배추절임을 기계화자동화하기 위해 적정 기계화 절임 조건의 표준화, 중 - 대형 김치 공장에서 배추의 기계 화 절임의 주요 변수로, 염수 농도, 절임시간, 탈수 시간의 조사를 공장 규모로 진행시킨 연구도 있다(14). 그리고 배추 와 함께 절임배추의 중요한 요인인 소금 종류 및 이용실태, 절임배추 저장 중 폴리에틸렌 포장 필름 종류와 소금 절임 농도에 따른 품질 변화 등 다양한 연구들이 진행되었으나 (15-17). 계절별 배추에 관한 것이 아니라 주로 하나의 계절 에 대한 연구가 진행된 것이 대부분이다. 특히 계절별 배추 의 품질은 품종, 재배 조건 등 수확 전 후의 요인에 영향을 받고, 이를 이용한 주요 가공 식품인 김치의 품질에도 크게 영향을 미치는 것으로 알려져 있으나 많은 연구가 수행되지 않았다(18-20). 현재 계절별 배추로 절임배추를 생산하여 연중 소비자에게 제 공하는 절임 업체에서는 계절별로 제조 된 절임배추 특성을 연구하여 계절별 절임배추의 현장형 절임 조건 기준을 정하는데 다양한 자료가 요구되고 있다.

본 연구는 대형 절임배추 제조 공장에서 제조된 계절별 절임배추의 물리화학적 및 미생물학적 특성을 조사하여 계절별 절임배추의 절임 조건을 제시 및 저장성 연장 연구 를 위한 기초 자료로 이용하고자 수행되었다.

\section{재료 및 방법}

재 료

본 실험에 사용된 계절별 배추는 봄배추(춘광, 2013년 6월 수확), 가을배추(추광, 2013. 11월 수확), 월동배추(남도 장군, 2013년 3월 수확)는 전라남도 해남에서 재배한 것이 었고, 여름 배추는 강원도 평창에서 재배된 고랭지 배추 (2013년 9월 수확)를 실험에 사용하였다. 절임배추 제조는 해남 화원농협(Haenam-gun, Jeollanam-do, Korea)에서 $\mathrm{HACCP}$ 절임배추 제조 라인에서 제조된 절임배추를 $0^{\circ} \mathrm{C}$ 로 유지된 냉장 수송차에 온도 로거를 부착하여 제조 직후 12 시간 이내로 제공받아 실험하였다. 이때 해남 화원농협 의 절임배추 제조 라인은 배추를 이절, 1 차 정선, 2 단계 절임, 4단계 세척, 선별, 탈수, 포장의 공정과정을 거치는데, $\mathrm{HACCP}$ 규정하에 절임실, 세척수, 절임수, 절임배추의 품 온, 절임수 염도 및 절임배추 제조 후의 절임배추의 염도, $\mathrm{pH}$, 고형분 함량을 매일 측정하고 있다. 절임 공정 라인을
조사 분석한 결과 절임실과 세척수 온도는 $15 \sim 20^{\circ} \mathrm{C}$ 였고, 절임수 염도 약 10 14\%에서 약 24시간 절임을 한 후 10 1 $5^{\circ} \mathrm{C}$ 내외의 세척수로 4 단계의 세척을 통과한 절임배추를 탈수 그물망 컨베어에 약 5 6분 정도 탈수 한 후 포장 단계 를 거친다. 절임배추 1 일 생산량은 계절별로 차이가 있는데, 봄배추는 1 일 생산량 약 5 톤, 여름배추 5 톤, 가을배추 100 톤, 월동 배추 30 톤이었다. 본 실험에 사용한 시료는 각 계절별 로 생산되어 $10 \mathrm{~kg}$ 단위로 포장된 절임배추 15 상자를 제공 받았고, 반포기당 절임배추의 무게는 약 $1.5 \sim 1.8 \mathrm{~kg}$ 였고, 절임배추 소금농도는 약 $1.3 \sim 1.5 \%$ 의 범위였다. 각 계절별 로 한 상자에서 반포기씩 비슷한 크기의 것을 취하여 실험 재료로 사용하였다.

\section{$\mathrm{pH}$ 및 적정산도}

절임배추 시료 반포기 약 $1.5 \sim 1.8 \mathrm{~kg}$ 를 $1 / 4$ 로 세로로 자른 후 blender(MR-5550 MFP, Braun, Poland)로 갈아 반죽 (paste) 상태의 시료를 제조한 후 electrode를 직접 넣어 $\mathrm{pH}$ (827, Metrohm, Z.finyen, Switzerland)를 측정하였다. 적정 산도는 blender로 간 반죽상태의 시료 $1 \mathrm{~g}$ 을 정확히 달아 $100 \mathrm{~mL}$ 로 희석한 후 Toyo No.1로 여과한 다음 여액 20 $\mathrm{mL}$ 를 취하여 $0.01 \mathrm{~N} \mathrm{NaOH}$ 용액으로 $\mathrm{pH}$ 가 8.3이 될 때까지 적정하여 소비된 $0.01 \mathrm{~N} \mathrm{NaOH}$ 용액 소비량을 구한 후 젖산 으로 환산하여 표시하였다(21).

\section{염 함량 및 가용성 고형분 함량}

염 함량은 절임배추 시료를 세로로 $1 / 4$ 로 잘라 페이스트 상태로 제조한 시료 $1 \mathrm{~g}$ 을 정확히 달아 $100 \mathrm{~mL}$ 로 희석한 후 여과한 여액 $10 \mathrm{~mL}$ 을 취하고 $2 \%$ potassium chromate $1 \mathrm{~mL}$ 를 넣어 $0.02 \mathrm{~N} \mathrm{AgNO}_{3}$ 용액으로 적정하는 $\mathrm{Mohr}$ 법에 의해 측정하였다(22). 가용성 고형분(soluble solid content) 은 페이스트 상태의 배추 시료를 거즈로 여과한 다음 디지 털 당도계(PDX-1, VeeGee, USA)를 이용하여 각 처리구당 5 회 반복하여 평균값을 구하였다.

\section{미생물 균수}

절임배추를 $100 \mathrm{~g}$ 씩 취하여 $0.85 \%$ 멸균식염수 용액으로 10 배 희석하여 stomacher(Bagmixer, Duksan, Seoul, Korea) 를 이용하여 균질화 하였다. 균질액 $1 \mathrm{~mL}$ 를 취하여 $0.85 \%$ 멸균식염수에 단계적으로 희석한 후 $1 \mathrm{~mL}$ 씩 pouring culture method로 접종하였다. 각각 총균수와 젖산균수는 $37^{\circ} \mathrm{C}$ 에서 48시간 배양한 후 colony 수를 측정하여 colony forming unit $(\mathrm{CFU} / \mathrm{g})$ 으로 표시하였다(23).

\section{색도 및 조직감}

절임배추의 색도는 페이스트 상태의 시료를 직경 $5 \mathrm{~cm}$, 높이 $5 \mathrm{~mm}$ 의 원형 플라스틱 틀에 넣어 색도계(CR-410, Minolta Co., Osaka, Japan)를 이용하여 측정하였다. 측정 
전 표준백판으로 보정한 후 사용하였으며 L(명도, lightness), $\mathrm{a}$ (적색도, redness) 및 $\mathrm{b}$ (황색도, yellowness)값으로 나타내 었다(24).

절임배추의 조직감 측정은 2 가지 방법으로 나누어 측정 하였다. 첫 번째는 디지털 경도계(IMADA push pull scale \& digital force gauge, IMADA, Japan)를 이용하여 probe(v자 형) 로 배추 표면을 눌렀을 때 발생하는 힘을 측정하였으며 각 처리구당 10 번씩 반복하였다(firmness). 두 번째는 texture analyzer(TAXT-2, Stable Micro Systems, Ltd., Godalming, England)를 사용하였고, puncture test를 시행하 였다. 즉, 배추 표면의 중앙부분에서부터 $100 \%$ 관통하면서 받는 최대 강도(hardness)와 probe가 배추 표면에 닿은 후부 터 배추 조직의 겉면이 뚫릴 때까지의 시간을 배추 두께로 경도 측정 시 그래프에 나타나는 peak 수를 측정하였으며 시료 측정 횟수는 각 처리구당 15 회 반복하여 평균값을 구하였다. 이때 측정 조건은 probe $3 \mathrm{~mm}$, pretest speed 5 $\mathrm{mm} / \mathrm{s}$, test speed $0.5 \mathrm{~mm} / \mathrm{s}$, posttest speed $10 \mathrm{~mm} / \mathrm{s}$ 였다. 이때 절임배추 시료는 일관성을 위해 포기 전체를 대표할 수 있는 겉잎에서 3 4번엽을 사용하여 줄기 부분 중 뿌리에 서 $5 \mathrm{~cm}$ 떨어진 가장 두꺼운 부분을 측정 부위로 하였다.

\section{통계분석}

계절별 절임배추의 물리화학적 및 미생물 품질 차이를 파악하기 위해 분산분석(analysis of variance)을 실시하였 다. 또 이들 품질 요인간의 상관분석(correlation analysis), 주성분 분석(principle component analysis) 및 계층적 군집 분석(hierachical cluster analysis)을 실시하였다. 통계분석은 SAS(7.2, SAS Institute, Cary, NC, USA)와 XLSTAT(2007.1 Addinsoft, NY, USA)를 이용하여 실시하였다.

\section{결과 및 고찰}

\section{계절별 절임배추의 품질 특성}

봄배추, 여름배추, 가을배추 및 겨울배추를 이용하여 대 형 절임배추 공장에서 $\mathrm{HACCP}$ 조건으로 절임을 한 절임배 추의 물리화학적 및 총균수 등의 특성을 비교하여 평균값과 통계분석을 실시하였다(Table 1). 절임배추 제조 후 12 시간 이내에 측정된 배추의 $\mathrm{pH}$ 는 가을배추로 절임한 시료가 $6.02 \pm 0.04$ 로 다른 계절에 수확하여 제조한 절임배추 시료 보다 통계적으로 높은 값을 보였고, 봄배추와 월동배추는 각각 $5.94 \pm 0.05,5.89 \pm 0.09$ 로 비슷한 $\mathrm{pH}$ 를 보였고, 여름배 추가 가장 낮은 $5.88 \pm 0.05$ 였다. 적정산도의 경우 통계적으 로 가을배추 시료가 $0.15 \pm 0.01 \%$ 로 가장 낮은 값을 보인 반면, 봄배추와 가을배추가 각각 $0.23 \pm 0.02 \%, 0.24 \pm 0.02 \%$ 였고, 여름 배추가 $0.28 \pm 0.05 \%$ 로 유의적인 차이가 없었다. 이는 절임배추의 초기 $\mathrm{pH}$ 가 6.05 정도라고 보고한 Lee 등
(19)과 Park 등(25)의 가을 김장 배추 10 종의 품종으로 동일 조건으로 제조한 절임배추의 초기 $\mathrm{pH}$ 가 5.94 6.11의 범위 안에 포함되는 범위였다. 또 시중에서 판매되고 있는 절임 배추 15 종을 2010 년 2월에 구입하여 $\mathrm{pH}$ 측정 결과 최저 5.32 에서 최대 6.47로 넓은 범위를 보였다고 보고되었는데, 이는 제조 공정 차이와 절임배추 제조 후의 보관 상태, 시간 경과에 따라 $\mathrm{pH}$ 범위가 넓게 나타나는 것으로 판단된다 (14). 또 적정산도의 경우도 Lee 등(19)의 초기 적정산도가 $0.09 \sim 0.11 \%$ 라고 보고된 결과와 비교할 때 본 실험 결과 약간 높은 범위를 나타냈으나, $\operatorname{Han}$ 등(7)의 결과와는 유사 하였다.

한편 배추의 가용성 고형분 함량의 경우 월동배추가 $7.76 \pm 0.39 \%$ 로 다른 계절의 시료보다 유의적인 차이로 높은 값을 보였고, 여름배추와 가을배추 및 봄배추는 각각 $6.18 \pm 0.41 \%, 6.29 \pm 0.38 \%, 5.95 \pm 0.25 \%$ 로 나타났다. 절임 배 추의 염도는 봄배추와 월동배추가 $1.59 \pm 0.09 \%, 1.55 \pm$ $0.56 \%$, 여름배추와 가을배추는 각각 $1.38 \pm 0.07 \%, 1.31 \pm$ $0.07 \%$ 값을 보였고, 통계적으로 유의적인 차이는 없었다. 절임배추의 밝기를 나타내는 $\mathrm{L}$ 값의 경우 $42.17 \pm 3.96$ $\sim 49.687 \pm 2.638$ 의 범위로 계절별로 유의적인 차이를 보이지 않았다. 붉은색을 나타내는 a값은 $-6.07 \pm 1.49 \sim-7.30 \pm 1.17$, 황색도를 나타내는 $\mathrm{b}$ 값은 $13.77 \pm 0.95 ~ 15.98 \pm 1.63$ 로 계절별 절임배추 간 유의적인 차이를 보이지 않았다. 이는 절임배 추 제조시 품종이나 계절별 배추에 상관없이 겉잎이 제거된 원료를 사용하기 때문에 색의 차이가 크지 않은 것으로 보인다.

계절별 절임배추의 조직감의 경우 현장형 디지털 경도계 로 절임배추를 눌렀을 때의 경도(firmness)의 경우, 봄배추 가 가장 높은 $4.92 \pm 0.06 \mathrm{~kg}_{\mathrm{f}}$ 로 가장 높았고, 여름배추와 가을 배추는 각각 $4.26 \pm 0.18,4.14 \pm 0.34 \mathrm{~kg}_{\mathrm{f}}$, 겨울배추 $3.91 \mathrm{~kg}_{\mathrm{f}}$ 로 시료 간 유의적인 차이가 없었다. 반면에 절임배추 표면을 관통시킬 때의 경도(hardness)는 여름 배추가 $11.71 \pm 0.53$ $\mathrm{kg}_{\mathrm{f}}$ 로 가장 높았고, 나머지 계절별 배추는 $9.42 \pm 0.29$ $9.71 \pm 1.04 \mathrm{~kg}_{f}$ 의 비슷한 경도를 보였다. 절임배추를 관통시 키는데 걸리는 시간은 절임배추의 두께(width)로 볼 수 있 는데, 월동배추가 $34.31 \pm 4.00 \mathrm{~mm}$ 으로 가장 두꺼웠고, 봄배 추는 $27.50 \pm 7.62 \mathrm{~mm}$, 여름배추는 $25.94 \pm 2.52 \mathrm{~mm}$, 가을배 추는 $23.08 \pm 1.4 \mathrm{~mm}$ 였다. 또 절임배추의 아삭아삭한 조직감 으로 표현되는 peaks 수 경우 가을배추가 23.36 \pm 5.12 개로 가장 높은 피크수를 보였고, 여름배추 $14.47 \pm 1.85$, 겨울배 추 $13.69 \pm 3.41$, 봄배추 $9.36 \pm 0.48$ 순이었다. 절임배추의 경 도는 절임시간, 절임온도의 영향을 받는데, 낮은 온도에서 의 절임이 높은 온도에서의 절임보다 경도가 낮다는 보고 (26)와 절임 온도가 낮을 경우 경도가 높았다는 보고(9)와 상반되는 결과 보고가 있다. 본 연구결과도 디지털 경도계 로 측정한 firmness의 경우 봄배추가 가장 높은 경도를 보인 반면 texture analyser에 의한 hardness는 여름 배추가 가 
Table 1. Physicochemical and microorganism characteristics of seasonal salted-Kimchi cabbage

\begin{tabular}{|c|c|c|c|c|c|}
\hline \multirow{2}{*}{\multicolumn{2}{|c|}{ Quality characteristics }} & \multicolumn{4}{|c|}{ Seasonal cultivar of salted Kimchi cabbage } \\
\hline & & Spring & Summer & Fall & Winter \\
\hline \multicolumn{2}{|l|}{$\mathrm{pH}$} & $5.94 \pm 0.05^{\text {abl })}$ & $5.88 \pm 0.05^{\mathrm{b}}$ & $6.02 \pm 0.04^{\mathrm{a}}$ & $5.89 \pm 0.09^{\mathrm{b}}$ \\
\hline \multicolumn{2}{|c|}{ Titratable acidity $(\%)$} & $0.23 \pm 0.02^{\mathrm{a}}$ & $0.28 \pm 0.05^{\mathrm{a}}$ & $0.15 \pm 0.01^{\mathrm{b}}$ & $0.24 \pm 0.02^{\mathrm{a}}$ \\
\hline \multicolumn{2}{|l|}{ Soluble solid $(\%)$} & $5.95 \pm 0.25^{\mathrm{b}}$ & $6.18 \pm 0.41^{\mathrm{b}}$ & $6.29 \pm 0.38^{b}$ & $7.76 \pm 0.39^{\mathrm{a}}$ \\
\hline \multicolumn{2}{|l|}{ Salt content $(\%)$} & $1.59 \pm 0.09^{\mathrm{a}}$ & $1.38 \pm 0.07^{\mathrm{a}}$ & $1.31 \pm 0.07^{\mathrm{a}}$ & $1.55 \pm 0.56^{\mathrm{a}}$ \\
\hline \multirow{3}{*}{ Color value } & Lightness (L) & $46.41 \pm 3.98^{\mathrm{a}}$ & $49.68 \pm 2.63^{\mathrm{a}}$ & $46.26 \pm 0.45^{\mathrm{a}}$ & $42.17 \pm 3.96^{\mathrm{a}}$ \\
\hline & Redness (a) & $-7.30 \pm 1.17^{\mathrm{a}}$ & $-6.12 \pm 0.74^{a}$ & $-6.07 \pm 1.49^{\mathrm{a}}$ & $-6.55 \pm 2.78^{\mathrm{a}}$ \\
\hline & Yellowness (b) & $15.98 \pm 1.63^{\mathrm{a}}$ & $13.77 \pm 0.95^{\mathrm{a}}$ & $14.32 \pm 2.15^{\mathrm{a}}$ & $14.49 \pm 0.50^{\mathrm{a}}$ \\
\hline \multirow{4}{*}{ Texture properties } & Firmness (kg force) & $4.92 \pm 0.06^{\mathrm{a}}$ & $4.26 \pm 0.18^{\mathrm{b}}$ & $4.14 \pm 0.34^{\mathrm{b}}$ & $3.91 \pm 0.39^{b}$ \\
\hline & Hardness ( $\mathrm{kg}$ Force) & $9.42 \pm 0.29^{b}$ & $11.71 \pm 0.53^{\mathrm{a}}$ & $9.71 \pm 1.04^{b}$ & $9.65 \pm 2.10^{b}$ \\
\hline & Width (mm) & $27.50 \pm 7.62^{\mathrm{ab}}$ & $25.94 \pm 2.52^{\mathrm{ab}}$ & $23.08 \pm 1.4^{b}$ & $34.31 \pm 4.00^{\mathrm{a}}$ \\
\hline & Peaks No. & $9.36 \pm 0.48^{b}$ & $14.47 \pm 1.85^{b}$ & $23.36 \pm 5.12^{\mathrm{a}}$ & $13.69 \pm 3.41^{b}$ \\
\hline \multicolumn{2}{|c|}{ Total bacteria (log CFU/g) } & $4.88 \pm 0.46^{\mathrm{b}}$ & $6.88 \pm 0.95^{\mathrm{a}}$ & $5.92 \pm 0.39^{\mathrm{ab}}$ & $4.72 \pm 0.54^{b}$ \\
\hline \multicolumn{2}{|c|}{ Lactic acid bacteria (log CFU/g) } & $4.81 \pm 0.50^{\mathrm{ab}}$ & $6.03 \pm 1.06^{\mathrm{a}}$ & $6.69 \pm 0.95^{\mathrm{a}}$ & $3.60 \pm 1.89^{b}$ \\
\hline
\end{tabular}

${ }^{1)}$ Means \pm SD ( $\left.\mathrm{n}=10\right)$ within each column followed by the same letter are not significantly different $(\mathrm{p}<0.05)$.

Table 2. Correlation coefficients between quality characteristics in the seasonal salted-Kimchi cabbage

\begin{tabular}{|c|c|c|c|c|c|c|c|c|c|c|c|c|c|c|}
\hline Variables & $\begin{array}{l}\text { Seasonal } \\
\text { cultivar }\end{array}$ & $\mathrm{pH}$ & $\begin{array}{c}\text { Titratable } \\
\text { acidity }\end{array}$ & $\begin{array}{l}\text { Soluble } \\
\text { solid }\end{array}$ & Salt & $\begin{array}{c}\text { Total } \\
\text { microbes }\end{array}$ & $\begin{array}{c}\text { Lactic } \\
\text { acid } \\
\text { bacteria }\end{array}$ & $\begin{array}{l}\text { Lightness } \\
\text { (L) }\end{array}$ & $\begin{array}{l}\text { Redness } \\
\text { (a) }\end{array}$ & $\begin{array}{l}\text { Yellowness } \\
\text { (b) }\end{array}$ & Firmness & Hardness & Width & $\begin{array}{c}\text { Peaks } \\
\text { No. }\end{array}$ \\
\hline Seasonal cultivar & 1 & & & & & & & & & & & & & \\
\hline $\mathrm{pH}$ & -0.062 & 1 & & & & & & & & & & & & \\
\hline Titratable acidity & -0.281 & -0.494 & 1 & & & & & & & & & & & \\
\hline Soluble solid & $0.741^{* *}$ & -0.437 & 0.261 & 1 & & & & & & & & & & \\
\hline Salt & $-0.817^{* *}$ & 0.046 & 0.278 & $-0.599^{*}$ & 1 & & & & & & & & & \\
\hline Total microbes & -0.157 & 0.359 & -0.148 & -0.359 & -0.233 & 1 & & & & & & & & \\
\hline Lactic acid bacteria & 0.229 & 0.213 & -0.177 & -0.042 & -0.109 & 0.312 & 1 & & & & & & & \\
\hline Lightness (L) & -0.576 & $0.665^{* *}$ & -0.054 & $-0.661^{*}$ & $0.624^{*}$ & 0.426 & 0.245 & 1 & & & & & & \\
\hline Redness (a) & -0.341 & $0.806^{* *}$ & -0.117 & $-0.658^{*}$ & 0.293 & 0.546 & 0.301 & $0.823^{* *}$ & 1 & & & & & \\
\hline Yellowness (b) & -0.131 & 0.241 & -0.244 & -0.073 & 0.451 & -0.468 & -0.089 & 0.313 & -0.076 & 1 & & & & \\
\hline Firmness & $-0.802^{* *}$ & -0.286 & 0.200 & -0.433 & $0.596^{*}$ & -0.042 & -0.373 & 0.173 & -0.198 & 0.319 & 1 & & & \\
\hline Hardness & -0.143 & -0.171 & 0.390 & 0.171 & 0.090 & 0.419 & 0.184 & 0.275 & 0.080 & -0.329 & -0.034 & 1 & & \\
\hline Width & 0.371 & $-0.852^{* *}$ & 0.389 & 0.559 & -0.233 & -0.567 & -0.166 & $-0.821^{* *}$ & -0.739 & -0.310 & -0.105 & -0.117 & 1 & \\
\hline Peaks No. & 0.441 & 0.563 & $-0.790^{* *}$ & -0.177 & $-0.577^{*}$ & 0.532 & 0.339 & 0.050 & 0.370 & -0.234 & -0.540 & -0.170 & -0.410 & 1.00 \\
\hline
\end{tabular}

"significant at $\mathrm{p}<0.05,{ }^{* *}$ significant at $\mathrm{p}<0.01$

장 높은 경도를 보였다. 즉 절임배추 조직감의 경우 절임농 도, 절임온도 등 이외에 측정 방법에 따라 경도 차이를 보여 절임배추로 제조된 김치의 품질에 영향을 주는 조직감에 대한 연구도 실제 섭취하였을 때의 관능검사와 함께 다양한 측면에서 연구가 진행되어야 할 것으로 판단된다.

한편 총균수는 여름 배추가 $6.88 \pm 0.95 \log \mathrm{CFU} / \mathrm{g}$ 로 가장 높았고, 가을배추 $5.92 \pm 0.39 \log \mathrm{CFU} / \mathrm{g}$, 봄배추와 월동배추
는 $4.72 \pm 0.54 \log \mathrm{CFU} / \mathrm{g}, 4.88 \pm 0.46 \mathrm{CFU} / \mathrm{g}$ 였다. 젖산균은 여름배추와 가을배추가 각각 $6.03 \pm 1.06,6.69 \pm 0.95 \mathrm{log}$ $\mathrm{CFU} / \mathrm{g}$, 봄배추와 월동배추가 각각 $4.81 \pm 0.50 \log \mathrm{CFU} / \mathrm{g}$, $3.60 \pm 1.89 \log \mathrm{CFU} / \mathrm{g}$ 이었다. 이는 Kim 등(14)의 판매량이 많은 4 개 김치 업체에서 수거한 절임배추의 총균수가 4.17 8.08 $\log \mathrm{CFU} / \mathrm{g}$ 로 보고와 비교하여 그 범위 안에 들어 있었으나, 본 실험 결과 통계적으로 여름 절임배추가 총균 
수와 젖산균수가 다른 계절의 절임배추보다 높게 나타나 계절에 따른 절임배추의 작업장의 온도, 절임수 온도 등에 관한 연구도 함께 미생물의 변화도 연구되어야 한다고 사료 된다.

\section{품질특성간의 상관관계 및 통계분석}

계절별 절임배추의 물리화학적 및 미생물 품질 특성의 상관관계를 측정하였다(Table 2). 계절별 절임배추와 가용 성 고형분 함량과 $1 \%$ 유의수준에서 양의 염함량과 디지털 경도계로 측정한 경도는 음의 상관관계가 있는 것으로 나타 났다. 이는 Yoon 등(27)의 계절에 따른 배추의 절임 용수의 고형물 함량 변화를 측정한 결과 월동 배추가 가장 많은 함량을 보였다는 결과와 Lee 등(19)의 봄배추와 가을배추 의 생육정도와 성분 분석 결과 가을배추의 가용성 고형물 함량이 봄배추보다 많고 배추자체의 품종별보다는 재배 계절에 따른 차이가 크다는 보고와 유사하게 계절별 배추에 따른 차이를 보였다. 또 동일한 염함량으로 절임을 할 경우 계절별 절임배추의 염농도가 차이가 있다는 보고(27)와 유 사하게 거의 동일한 조건에서 절임배추를 제조한 경우 계절 별 차이가 있다는 결과를 보였다. 이외에 절임배추의 $\mathrm{pH}$ 는 밝기를 나타내는 L값과 a값이 5\% 유의 수준에서 양의 상관 관계를 보였고, 배추의 두께와는 음의 상관관계를 나타내
었다. 적정산도는 조직감 측정시의 피크 개수와 $1 \%$ 유의 수준에서 음의 상관관계를 나타내었고, 가용성 고형분 함 량은 소금함량, $\mathrm{L}$ 값과 $\mathrm{a}$ 값과 음의 상관관계를 보였다. 즉 동일 조건으로 제조된 계절별 절임배추라도 계절에 따른 품질 차이를 확인할 수 있었는데, 특히 가용성 고형분 함량 과 절임배추의 소금 함량, 조직감 중 경도와 높은 상관관계 를 보였다.

계절별 절임배추 품질 특성의 주성분 분석(principal component analysis) 결과는 Fig. 2와 같다. 첫 번째 주성분 (F1)과 두 번째 주성분(F2)는 전체 데이터의 $35.59 \%$ 와 $27.28 \%$ 의 설명력을 보여 주었고, 총설명력은 $62.87 \%$ 였다. 주성분 $\mathrm{F} 1$ 은 계절별 배추, 밝기, 가용성 고형분함량, 배추 두께, 총균수와 젖산균 수로 이화학 및 물리적 품질 특성이 었고, 주성분 F2는 절임배추의 피크 개수로 물성 특성이었 다. 각 품질 특성의 분포를 보면 $\mathrm{F} 1$ 의 오른쪽으로 총균수, ligthness, redness, $\mathrm{pH}$, 염함량, 경도 등이 분포하였고, 왼쪽 에는 계절별, 고형분 함량, 배추 두께 등이 분포되었다. F2 상으로는 Y 축 양이 방향으로 계절별, 피크수, 미생물 균수, $\mathrm{pH}$ 가 음의 방향으로는 총산도, 염함량, firmness가 분포되 어 있는데, 각각의 특성이 명확하게 구분되지 않고, 절임배 추의 전반적인 특성이 F1과 F2 그래프 상에 전체적으로 분포되어 있었다. 한편 계절별 시료의 경우 겨울배추는 F1

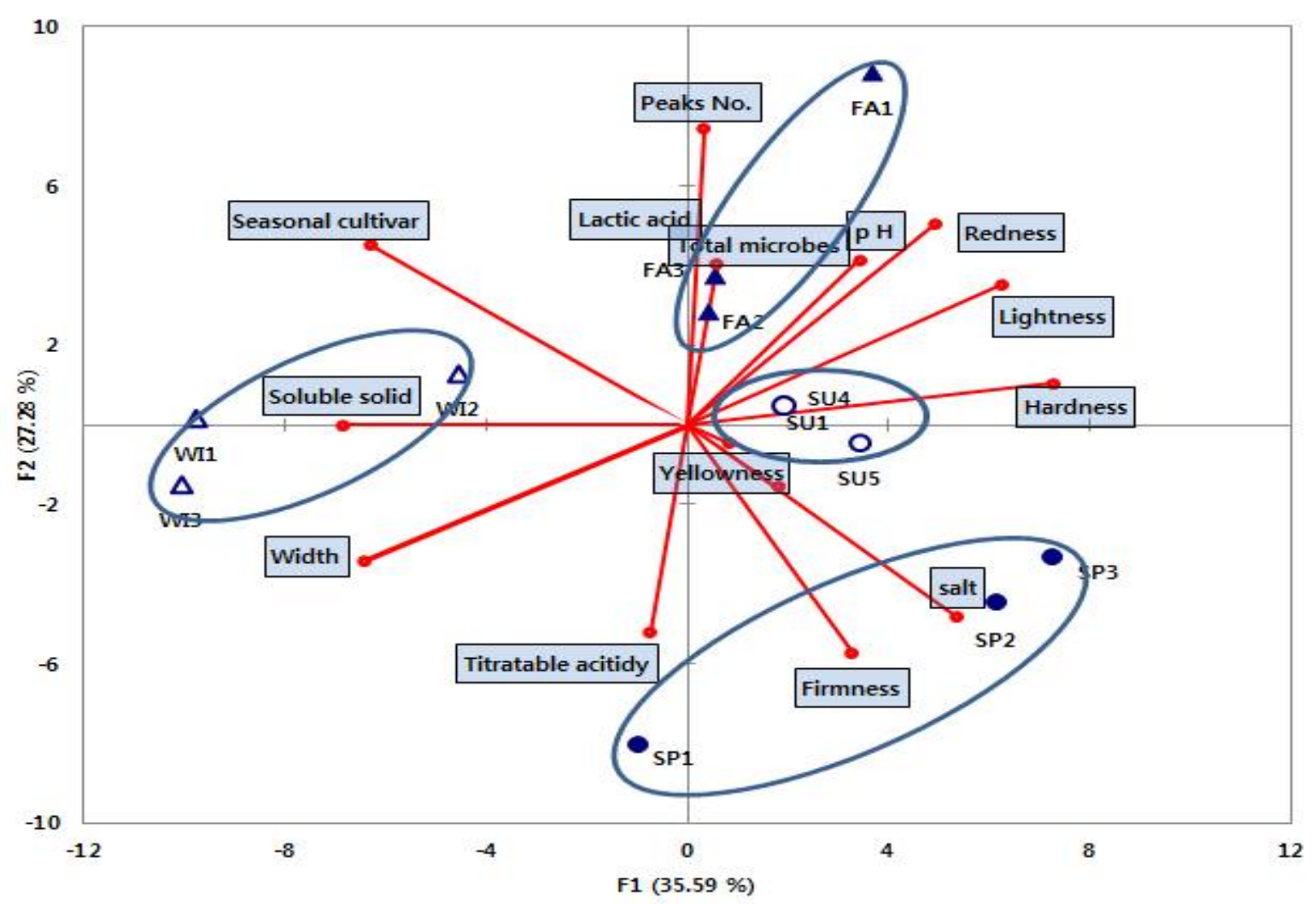

Fig. 1. Principal component analysis of quality characteristics of seasonal salted-Kimchi cabbage SP: spring salted-Kimchi cabbage, SU: summer salted-Kimchi cabbage, FA: fall salted-Kimchi cabbage, WI:winter salted-Kimchi cabbage. 


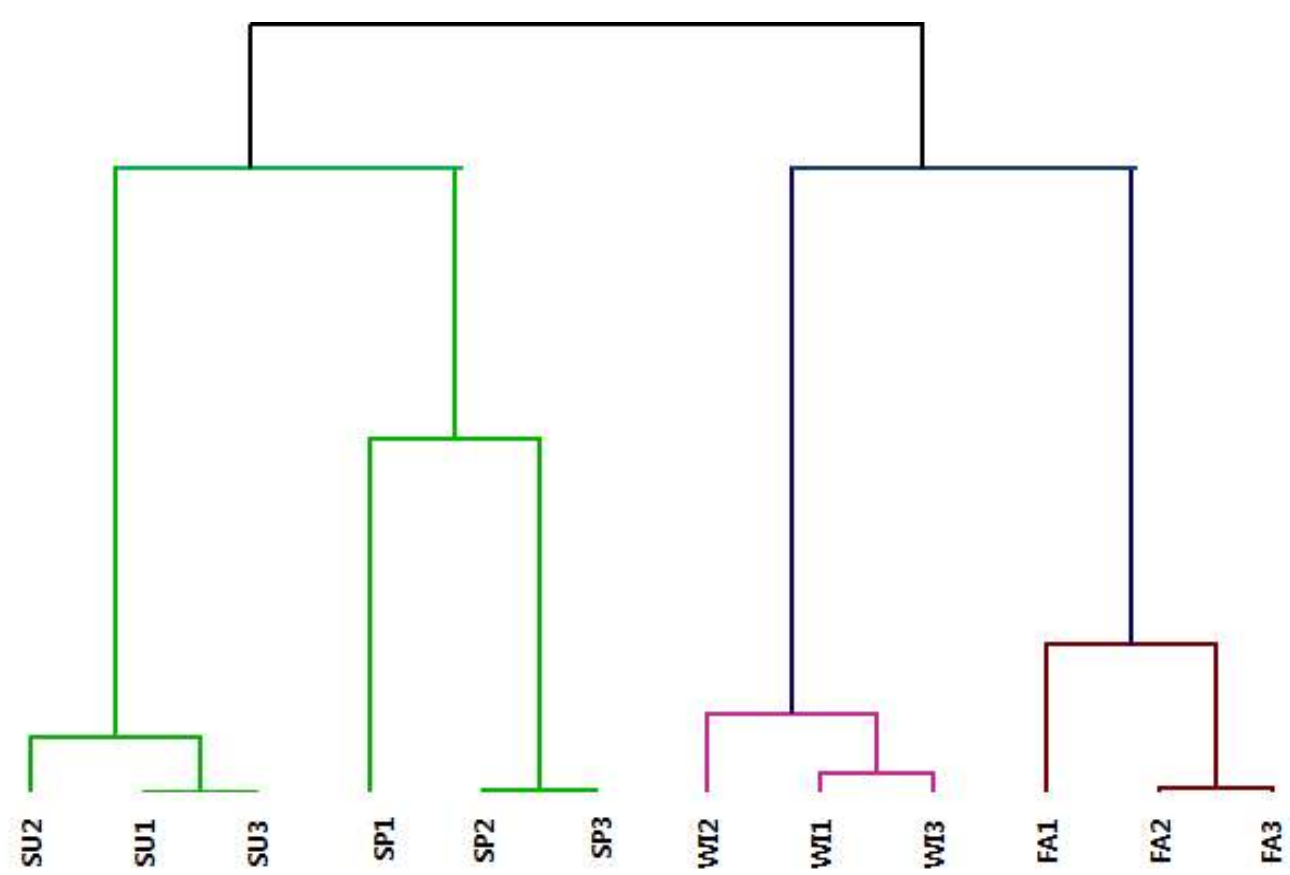

Fig. 2. Dendrogram of seasonal salted-Kimchi cabbage by agglomerative hierarchical clustering (AHC) based on quality characteristics of salted-Kimchi cabbage

SP: spring salted-Kimchi cabbage, SU: summer salted-Kimchi cabbage, FA: fall salted-Kimchi cabbage, WI:winter salted-Kimchi cabbage.

상의 왼편 중간에 분포하고, 가을배추는 그래프 상의 F1상 의 오른쪽 윗쪽에 분포하였으며, 여름배추는 겨울배추와 반대 방향에 봄배추는 F1상의 오른쪽 아래에 분포하여 계 절별 절임배추의 품질 특성이 전반적으로 차이가 있는 것을 확인하였다. 한편 Fig. 3은 계절별 절임배추의 품질 특성을 바탕으로 계층적 군집분석(hierarchical cluster analysis based on euclidean distance and Ward linkage)한 결과를 덴드로그램으로 도시한 것이다. 계절별 절임배추의 군집분 석 결과 각 계절별 절임배추가 각각 분류되었고, 군집간의 거리를 바탕으로 살펴보면 여름배추(SU1, SU2, SU3)와 봄 배추(SP1, SP2, SP3)가 가까운 거리에 위치하였고, 월동배 추(WI1, WI2, WI3)와 가을배추(FA1, FA2, FA3)가 가까운 거리에 위치하였다.

이상의 결과에서 각각의 계절별 절임배추의 경우 물리화 학적 및 미생물학적 품질 특성에 차이가 있음을 확인하였 고, 고품질이면서 품질이 균일화된 절임배추를 연중 생산 하기 위해서는 계절별 배추 원료의 품질과 절임 적성 등에 많은 연구가 진행되어야 한다고 사료된다. 특히 배추 수급 안정화를 위하여 배추 저장과 함께 배추 과잉 생산시 절임 배추를 제조하여 저장을 한 후 필요시 사용하기 위해서 절임배추의 장기 저장 방법이 필요하다. 이와 같은 절임배 추의 저장성 연장 기술 개발을 위해서는 계절별 절임배추의 품질 균일화가 확립 후에 진행되어야 하므로 계절별 절임배 추에 대한 더 많은 연구가 필요하다.

\section{요 약}

본 연구는 계절별 배추 원료의 최적 절임 조건 및 저장성 연구를 위한 기초 자료 제공을 위하여 계절별 절임배추의 물리화학적 및 미생물학적 특성 조사와 이들 특성의 상관성 을 조사하였다. 계절별(봄배추, 여름배추, 가을배추 및 겨울 배추) 절임배추의 $\mathrm{pH}$ 와 적정산도의 경우 가을배추 시료가 $6.02 \pm 0.04$ 와 $0.15 \pm 0.01 \%$ 로 다른 계절의 절임배추 시료보다 $\mathrm{pH}$ 는 약간 높고 적정산도는 약간 낮았다. 가용성 고형분 함량은 월동배추가 $7.76 \pm 0.39 \%$ 로 가장 높았고, 염도 함량 은 계절별로 유의적인 차이가 없었다. 총균수의 경우 여름 배추가 다른 계절의 배추보다 유의적으로 많은 균수가 있었 고 색도는 유의적인 차이가 없었다. 조직감의 경우 경도 (firmness)는 봄배추가 가장 높은 $4.92 \pm 0.06 \mathrm{~kg}_{\mathrm{f}}$ 였고, 단단한 정도(hardness)는 여름 배추가 $11.71 \pm 0.53 \mathrm{~kg}_{\mathrm{f}}$ 로 가장 높게 측정되었다. 한편 계절별 절임배추의 품질 특성간 상관관 계를 분석한 결과 계절별 절임배추와 가용성 고형분 함량, 경도와 $1 \%$ 유의수준 유의적인 상관성이 있었다. 또 주성분 분석 결과 첫 번째 주성분(F1)과 두 번째 주성분(F2)는(은) 전체 데이터의 각각 $35.59 \%$ 와 $27.28 \%$ 의 설명력을 보여 주 었고, 총설명력은 $62.87 \%$ 였다. 주성분 $\mathrm{F} 1$ 은 계절, 밝기, 가 용성 고형분 함량, 배추 두께, 총균수와 젖산균 수였고, 주성 분 F2는 절임배추의 피크 개수였다. 계절별 절임배추의 품 질 특성을 바탕으로 계층적 군집분석 결과 봄배추, 여름배 추 그리고 가을과 월동 배추로 3 그룹으로 나뉘었다. 이상의 
결과에서 계절별 절임배추의 경우 물리화학적 및 미생물학 적 품질 특성에 차이가 있음을 확인하였고, 품질 균일화와 고품질의 절임배추를 연중 생산하기 위해서는 각 계절별 배추의 품질 특성과 절임 적성에 관한 많은 연구가 필요하 다고 사료된다.

\section{감사의 글}

본 연구는 농림축산식품부 - 농림수산식품기술기획평 가원 첨단생산기술개발사업의 연구비 지원으로 수행되었 으며, 이에 감사드립니다.

\section{References}

1. Al-Turki AI, Dick WA (2003) Myrosinase activity in soil. Soil Sci Soc Am J, 67, 139-145

2. Colditz GA, Branch LGM, Lipnick RJ, Willertt WC, Rosner B, Posner BM, Hennekens CH (1985) Increased green and yellow vegetable intake and lowed cancer deaths in an elderly population. Am J Clin Nutr, 41, 32-37

3. Ministry of Agriculture and Forestry (MAP). Statistics of vegetables production amount. MAD(http://www. mifaff.go.kr)

4. Lee JY (2004) A simplified method to evaluate major quality factors and its application to determine inheritability of tissue firmness and total soluble solids in chinese cabbage. MS Thesis, Chung-Ang Univ, Korea

5. Ministry of agriculture food and rural affairs, Korea agro-fisheries \& food trade corp. (2011, 2010) Raw material consumption survey according to food industry

6. Ku KH, Jeong MC, Chung SK (2013) Industrialization of salted chinese cabbages and fresh-cut chinese cabbage. Food Sci Industry, 46, 2-11

7. Han GJ, Choi HS, Lee SM, Lee EJ. Park SE, Park KY (2011) Addition of starters I pasteurized brined baechu cabbage increased Kimchi quality and health functionality. J Korean Soc Food Sci Nutr, 40, 110-115

8. Lee KH (2008) Effect of ozone treatment for sanitation of chinese cabbage and salted chinese cabbage. J Korean Soc Food Sci Nutr, 37, 90-96

9. Lee SW, Cho SR, Han SH, Rhee C (2009) Effects of the low temperature and low salt solution on the quality characteristics of salted chinese cabbage. Korean J Food Nutr, 22, 337-386
10. Park SS, Sung Jm, Jeong JW, Park KJ, Lim JH (2013) Quality changes of salted chinese cabbages with electrolyzed water washing and a low storage temperature. J Korean Soc Food Sci Nutr, 42, 615-620

11. Lee, MK, Yang HJ, Woo HN, Rhee YK, Moon SW (2011). Changes in the texture and salt contents of chinese cabbage using different salting methods. J Korean Soc Food Sci Nutr, 40, 1184-1188

12. Kim J, Park KY, Choi H, Yang J (2010) Quality evaluation of conventional salted cabbages. Korean $\mathbf{J}$ Food Nutr, 23, 659-663

13. Kim HO, Suh SR, Choi YS, Yoo SN (2007) Optimal conditions for mechanized salting process of salt-inserting method for winter cabbage to produce Kimchi. Korean J Food Preserv, 14, 695-701

14. Kim JH, Lee YK, Yang JY (2011) Change of harmful microorganisms in pickling process of salted cabbage according to salting and washing conditions. J Food Hyg Safety, 4, 417-423

15. Lee MH, Lee GD, Son KJ, Yoon SR, Kim JS, Kwon $\mathrm{JH}$ (2002) Changes in organoleptic and rheological properties of chinese cabbage with salting condition. J Korean Soc Food Sci Nutr, 3, 417-422

16. Hwang ES (2010) Changes in myrosinase activity and total glucosinolate levels in Korean chinese cabbages by salting conditions. Korean J Food Cookery Sci, 26, 104-109

17. Kim YW, Jung JK, Cho YJ, Lee SJ, Kim SH, Park KY, Kang SA (2009) Quality changes in brined baechu cabbage using different types of polyethylen film and salt content during storage. Korean J Food Preserv, 16, 605-611

18. Kim MJ, Hong GH, chung DS, Kim YB (1998) Quality comparison of Kimchi made from different cultivars of Chinese cabbage. Korean J Food Sci Technol, 39, 528-532

19. Lee IS, Park WS, Koo YJ, Kang KH (1994) Changes in some characteristics of brined Chinese changes of fall cultivars during storage. Korean J Food Sci Technol, 26, 239-245

20. Han ES (1994) Quality changes of salted chinese cabbage by packaging methods during storage. Korean J Food Sci Technol, 26, 283-287

21. AOAC (1996) Official method of analysis. $15^{\text {th }}$ ed. Association of official analytical chemists. Washington DC, USA, p 607

22. AOAC (1996) Official method of analysis. $15^{\text {th }}$ ed. 
Association of official analytical chemists. Washington DC, USA, p 1006

23. Collins CH, Lyne PM (1985) Microbiological methods. $5^{\text {th }}$ ed. Butterworth \& Co. Ltd., Boston. p 73, 130-133

24. Hutchings JS (1994). Food colour and appearance. Instrumental specification. Blackie Academic \& Professional, UK. p 217-223

25. Park WS, Lee IS, Han YS, Koo YJ (1994) Kimchi preparation with brined Chinese cabbage and seasoning mixture stored separately. Korea J Food Sci Technol, 26, 231-238

26. Kim WJ, Ku KH, Cho HO (1988) Changes in some physical properties of Kimchi during salting and fermentation. Korean J Food Sci Technol, 20, 483-487

27. Yoon HH, Kim DM (2000) Changes of brine characteristics during the salting process of winter, spring and summer Chinese cabbage. J Korean Soc Food Sci Nutr, 29, 26-29

(접수 2014년 4월 23일 수정 2014년 5월 19일 채택 2014년 5월 30일) 